\title{
Commercial Diplomacy to Increase Exports of Lampung Cocoa Commodities in the European Union Market
}

\author{
Astiwi Inayah \\ International Relations Department \\ Lampung University \\ Lampung, Indonesia \\ astiwi.inayah@fisip.unila.ac.id
}

\author{
Hani Damayanti Aprilia \\ Business Administration Department \\ Lampung University \\ Lampung, Indonesia \\ hani.damayanti@fisip.unila.ac.id
}

\author{
Yunia \\ International Relations Department \\ Lampung University \\ Lampung, Indonesia \\ yunia.1029@student.unila.ac.id
}

\begin{abstract}
Cocoa is one of Lampung's leading commodities. Lampung Province is currently actively carrying out commercial diplomacy activities, especially to increase exports of superior commodities to various countries. Lampung's cocoa exports are expected to increase in the international market, one of which is to countries in the European Union. Countries such as Switzerland, Germany, England, and Ireland are potential markets for Lampung to expand its business through cocoa or chocolate. This study aimed to analyze how commercial diplomacy is carried out both at local and global levels to increase cocoa commodity exports in the European Union market. This study used a qualitative approach. This study described the process related to commercial diplomacy to increase exports of Lampung cocoa in the European Union market. The results of the study provided an overview of the importance of commercial diplomacy to achieve economic interests in the export of cocoa commodities. Diplomacy at the local level that has been carried out by the Lampung Provincial Government, through the Department of Industry and Trade, consists of: carry out trade promotions by sending cocoa samples to several countries; engage business actors to take part in exhibitions; holding Focus Group Discussion (FGD) activities on the Acceleration of Trade Negotiations; conduct Export Coaching for export-oriented Small and Medium Enterprises (SMEs); and cooperate with the Ministry of Trade of the Republic of Indonesia. Meanwhile, diplomacy at the global level that has been carried out by the Government of Indonesia consists of: commercial diplomacy at the central government level carried out through Indonesia-the European Union Comprehensive Economic Partnership Agreement (IEUCEPA) to reduce cocoa tariffs in Europe while increasing consumption of Indonesian processed cocoa in the region; Indonesia becomes a member of the International Cocoa Organization (ICCO) in order to gain easy access to lobby European Union countries to reduce import duty on processed cocoa to $0 \%$; and Indonesia's cocoa diplomacy in the world's largest chocolate exhibition, Salon du Chocolat in Paris, France.
\end{abstract}

Keywords - commercial diplomacy, export, cocoa, Lampung, European Union

\section{INTRODUCTION}

Cocoa is one of Lampung's leading commodities in addition to other plantation products such as coffee, oil palm, pepper, and copra. Lampung's cocoa plantation centers are located in the districts of Tanggamus, South Lampung, East Lampung, West Coast, and Way Kanan. Cocoa is a commodity that contributes quite a lot of foreign exchange for Lampung. Data from the Industry and Trade Office of Lampung Province showed that in 2012, Lampung's cocoa export volume reached 29,118.00 tons. This number increased in 2013 to 31,408.00 tons. Lampung's cocoa exports during August 2013 were valued at 2.9 million US dollars with a volume of 1,295 tons, an increase compared to the same period in 2012 of 889 tons, generating foreign exchange of 1.9 million dollars. However, the export volume decreased quite significantly in 2014 to $6,672.40$ tons. Furthermore, data in 2017, 2018, and 2019 obtained from the Director General of Plantations showed an increase in Lampung cocoa production.

Cocoa production in Indonesia continues to increase, especially for areas such as Central Sulawesi, Southeast Sulawesi, South Sulawesi, West Sumatra, Aceh, and Lampung which are the largest cocoa producers in Indonesia. Indonesia in general and Lampung in particular have great potential to meet the growing demand for cocoa in the world every year. Unfortunately, producers in Indonesia are more focused on producing commodities and exporting raw materials. In fact, by adding value to commodities, it will have an impact on adding jobs and providing better income for farmers and for the country.

Indonesia has the opportunity to dominate the European Union's cocoa market. Data showed that chocolate consumption in countries in the Central European region is increasing rapidly, which is 6.2 $\mathrm{kg} / \mathrm{capita} /$ year. Chocolate consumption for 10 (ten) European countries in 2019 reached $6.2 \mathrm{~kg} / \mathrm{capita} /$ year where the consumption was dominated by Swiss chocolate consumption reaching $8.2 \mathrm{~kg} /$ capita/year, 
Germany reaching $7.9 \mathrm{~kg} / \mathrm{capita} /$ year, England and Ireland with each consumption reaching 7.4 $\mathrm{kg} / \mathrm{capita} /$ year. The high consumption of chocolate in the European Union is mainly for processed cocoa, which has a higher value than cocoa bean exports [1].

Switzerland, Germany, England, and Ireland have the opportunity to become targets for Indonesia to expand its business through cocoa or chocolate. The value of Indonesia's cocoa exports to the European Union in 2018 has reached more than 210 million US dollars. The data also showed an increase of $22 \%$ from the value of cocoa exports to the European Union in 2017 which only reached 201 million US dollars. The total value of Indonesia's cocoa exports to the European Union has only touched one percent of the total value of EU imports [1]. This means that the opportunity is still very big for Indonesia, especially for Lampung.

Lampung Province is currently actively carrying out commercial diplomacy activities, especially to increase exports of superior commodities to various countries. Lampung's cocoa exports are expected to increase in the international market, one of which is to European Union countries. Previous studies related to cocoa exports in the international market have not specifically discussed how commercial diplomacy is carried out to increase Lampung cocoa exports in the European Union market. This research focus on how commercial diplomacy is carried out at the local and global level to increase Lampung cocoa exports in the European Union market. The results of the study are expected to provide an overview of the importance of commercial diplomacy to achieve economic interests in the export sector of cocoa commodities. Thus, this research needs to be carried out immediately with the aim of supporting Lampung's economic growth.

\section{CONCEPTUAl Framework}

\section{A. Commercial diplomacy}

In scientific studies on commercial diplomacy, especially those aimed at achieving national interests, several studies have always focused on commercial diplomacy carried out at the global level (between consumer and producing countries). However, not many studies have focused on how commercial diplomacy is carried out at the local level. This is important because in Indonesia, foreign relations activities in the form of commercial diplomacy are carried out by several actors simultaneously, both by the central government, provincial governments, city/district governments, and agencies/institutions at the national and regional levels. Therefore, a study is needed on how to carry out commercial diplomacy both at local and global levels to increase exports of superior commodities to international markets.
The concept of commercial diplomacy will be used as a basis in this research to see how commercial diplomacy can be implemented to increase Lampung cocoa exports in the European Union market. Commercial diplomacy is one part of the larger framework of economic diplomacy. If economic diplomacy focuses on decision-making and negotiation activities in the fields of trade, investment, labor and the environment [2]. Then commercial diplomacy focuses only on promoting the export of goods and services as well as efforts to attract foreign investment (inward investment flow) [3].

Shutter (2007) create a dichotomy between economic diplomacy and commercial diplomacy. Commercial diplomacy is part of economic diplomacy with a focus on 4 main activities, namely trade promotion, making trade agreements, discussing multilateral trade issues and promoting foreign direct investment [3]. For many countries, including Indonesia, the second and third activities are the authority of the central government while the first and fourth activities can be carried out by all levels of government and all relevant export and investment promotion agencies.

By looking at this definition, it can be said that basically commercial diplomacy activities can be carried out by any state actor, both by the central government and local governments [4]. Killian (2013) states that in Indonesia, foreign relations activities in the form of commercial diplomacy are carried out by several actors simultaneously, both by the central government, provincial governments, city/district governments, and agencies/institutions at the national and regional levels [4]. At the national level, the Ministry of Foreign Affairs as the person in charge of Indonesia's diplomatic activities uses export and foreign investment figures as benchmarks to see the success of commercial diplomacy that has been carried out by Indonesia. Apart from the central government, commercial diplomacy is also carried out by various actors, including the provincial government. Several provincial governments in the territory of Indonesia are local governments that are quite active in conducting trade promotions and investment promotions in their regions.

Commercial diplomacy aims to increase the prosperity of a country. The level of prosperity of commercial diplomacy can be seen through its effectiveness. The effectiveness of commercial diplomacy that has been carried out by the local government and the central government needs to be analyzed. According to Zuidema (2012), the effectiveness of commercial diplomacy can be seen from the direct and indirect effects [5]. 


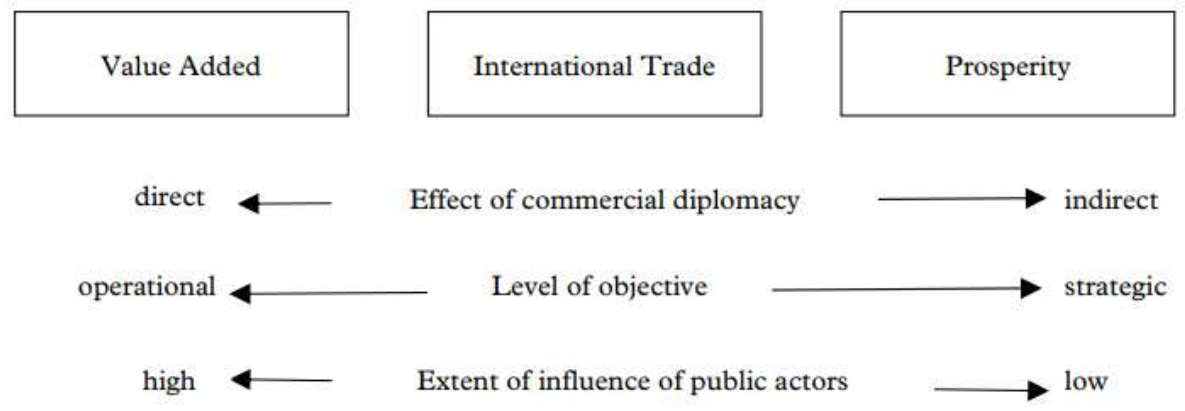

Fig. 1. the effectiveness of commercial diplomacy [5]

The direct effect is the added value obtained by the company, the local government, and the central government in a short period of time. The added value can be in the form of increasing income/money from commercial diplomacy efforts. However, these added values are not easy to identify. Furthermore, the indirect effect is through economic growth and welfare in the long term.

\section{B. Trade Liberalization}

Trade liberalization is a way for a country to open and facilitate access to trade with other countries [6]. It aims to increase economic growth by creating a free market and attracting capital from foreign investors to participate in investing their capital in countries that do trade liberalization. As for the ways to achieve trade liberalization, namely by eliminating various obstacles in international trade, both in the form of tariffs, such as customs duties and additional costs in transactions; as well as non-tariff forms, such as permits, quota limits, and so on [6]

In practice, trade liberalization is closely related to comparative advantage, where countries specialize in producing a commodity in international trade. Such specialization can be in the form of lower production costs compared to other countries. This comparative advantage is intended as a reinforcement of trade liberalization to maximize the country's profits in its leading sector [6]. For example, if country A has the advantage of producing textiles at low costs, and country B has the advantage of natural resources by producing spices at low costs, then the two countries can trade by applying their respective comparative advantages, where country $A$ with the main commodity of textiles and country B with the commodity of spices. The comparative advantage of the two countries can maximize their profits through their advantages. Therefore, trade liberalization is used to see the efforts that have been made by the central government to eliminate international trade barriers, especially cocoa exports. Meanwhile, comparative advantage is used to explain the potential of Lampung as a cocoa-producing province and its opportunities for export to European Union countries.

\section{RESEARCH METHODS}

The method used in this research is descriptive research, using a qualitative approach. This study described the process related to commercial diplomacy to increase exports of Lampung cocoa commodities to the European Union market which focuses on diplomacy efforts at local and global levels. Data collection techniques used in this study are 1. In-depth interviews, this technique is used to collect primary data related to the research focus. The interviews applied in this study were conducted in a structured manner using an interview guide. In this study, the interviewees were the Provincial Government, through the Industry and Trade Office of Lampung Province. 2. Literature Study. The data that has been collected are efforts that have been and will be made by the Lampung and Indonesian governments to increase cocoa exports to the European Union Market as well as various recommendations to increase cocoa exports, especially processed cocoa. In this study, data analysis is more focused during the process in the field along with data collection, processing, and after being in the field. The stages of data analysis followed the process of data reduction, data presentation, conclusion drawing, and verification.

\section{RESUlTS AND DISCUSSION}

\section{A. Potential of Lampung Province as Cocoa Producer in Indonesia}

Lampung is one of the largest cocoa-producing provinces in Indonesia. Lampung is ranked 1st on the island of Sumatra and ranked fifth at the national level as the province with the most cocoa production in 2020 


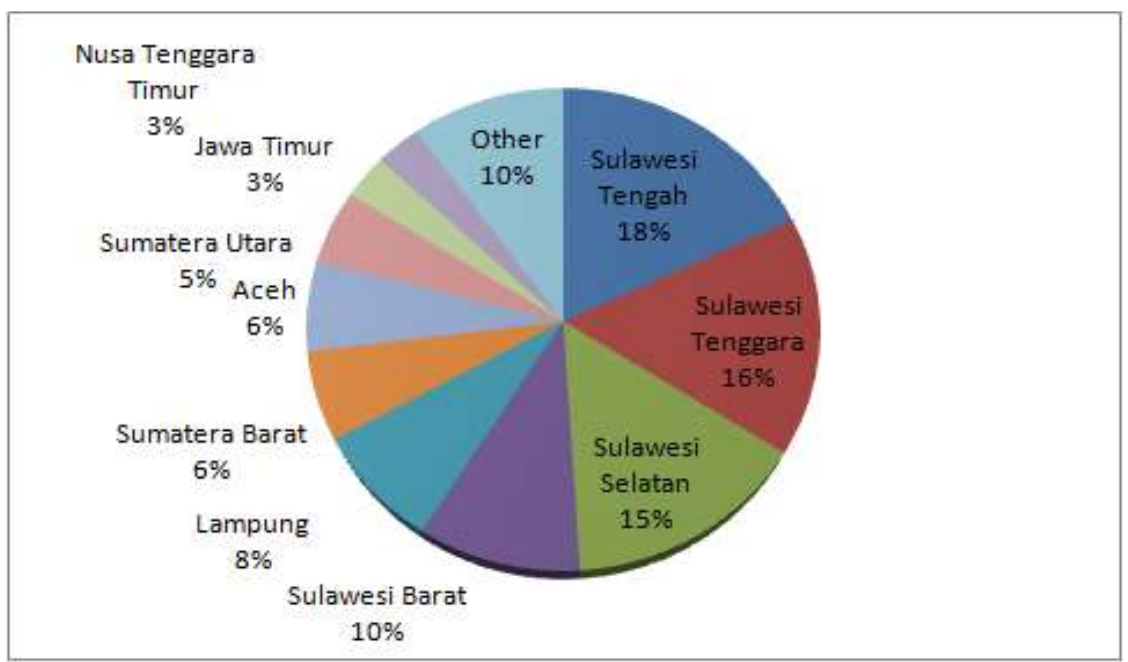

Fig. 2. Diagram of Cocoa Production by Province in 2020 [7]

Lampung has produced cacao as much as $8 \%$ of the total production in Indonesia. Lampung continued to experience an increase in cocoa production within three years, from 34,857 tons in 2017 to 58,642 tons in
2020 [7]. Then, Lampung also has the potential for a large cocoa area compared to other provinces such as East Nusa Tenggara, North Sumatera, East Java, and other provinces in Indonesia.

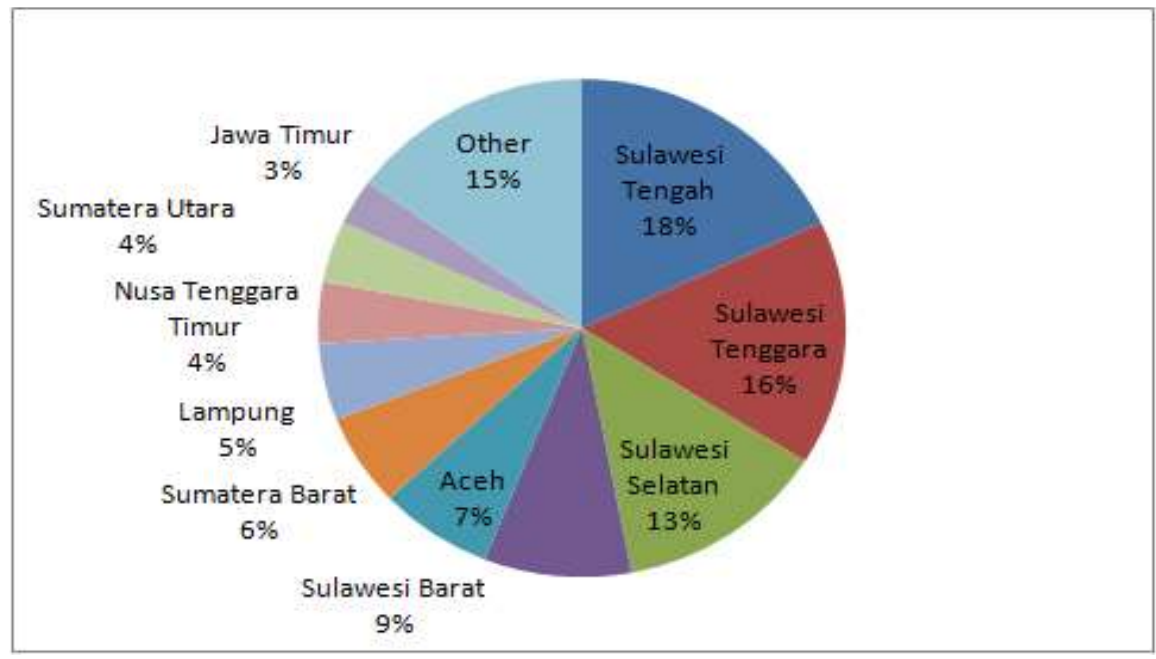

Fig. 3. Diagram Cocoa Area by Province in 2020 [7]

As much as $5 \%$ of the cocoa area in Indonesia is owned by the Province of Lampung. All regencies/cities in Lampung Province also have good enough land for cacao cultivation and so far the total cocoa area is 79,766 hectares [8]. Lampung has the second-largest cocoa area on the island of Sumatra after West Sumatra Province. The difference in cocoa area between the two provinces is only $2 \%$. Even so, Lampung has advantages over the provinces of West Sumatra, Central Sulawesi, Southeast Sulawesi, West Sulawesi, and Aceh which have a wider cocoa area. These provinces do not yet have a cocoa exporting company abroad. Meanwhile, Lampung has two of the largest cocoa exporting companies abroad, namely the Gunung Seminung company and the Ned Cofee Makmur Jaya company [9]. Therefore, Lampung has considerable potential compared to other provinces in terms of production volume, area, and cocoa export companies. These potentials are also an opportunity for Lampung to become a province that can meet the needs of cocoa exports to European Union countries which continue to increase every year.

\section{B. Commercial Diplomacy Carried Out At The Local Level}

Local governments as one of the actors in the practice of commercial diplomacy are required to have various plans and actions related to trade promotion and investment promotion as activities of commercial diplomacy practice. Lampung, as one of the largest cocoa-producing regions in Indonesia, is one of the areas that is focused on the practice of commercial diplomacy for cocoa products and their processed products. 
From the result of an interview with the Industry and Trade Office of Lampung Province (May 2021), as part of efforts to increase cocoa commodity exports in the international market, the Lampung Provincial Government through the Lampung Provincial Industry and Trade Office carried out trade promotions by sending cocoa samples to several countries such as Japan, India, Malaysia, Germany, Chile, and Dubai. Another effort is to involve business actors in participating in exhibitions by displaying various Lampung's leading commodities, one of which is cocoa, and providing information to buyers or investors that the productivity of cocoa in Lampung is competitive with cocoa in various cocoa-producing countries.

Based on the interview, there are various efforts that have been made by the Lampung Provincial Government through the Lampung Provincial Industry and Trade Office to increase Lampung cocoa exports to the European Union market, namely by holding activities such as FGD activities on the Acceleration of Trade Negotiations; Export Coaching for exportoriented SMEs, and cooperate with the Ministry of Trade of the Republic of Indonesia. The cooperation carried out by the Lampung Provincial Government with the Indonesian government (the Ministry of Trade) is by conducting: training to get buyers through Digital Marketing and other coaching facilitation such as socialization of providing information on global market opportunities, export training for potential exporters and exporters of cocoa. In addition, the Provincial Government of Lampung also cooperates with farmer groups, namely collaborating with the Agricultural Quarantine Center in conducting coaching activities for farmer groups of prospective cocoa exporters [10].

In the cocoa farmer development program, the Lampung Provincial Government cooperates with companies engaged in the agribusiness world. This collaboration is expected to be able to overcome various obstacles faced by cocoa farmers in Lampung and is expected to increase productivity and competitive prices for cocoa commodities. Seedlings of superior varieties are also given to cocoa farmers. However, there are still obstacles in terms of the availability of fertilizers so that the cocoa yields are not maximized even though they have used highyielding varieties. This obstacle is also a concern of the government, and gradually this obstacle will be overcome with a cooperation scheme such as the provision of superior seeds [10]

In addition to the efforts that have been made, the Provincial Government of Lampung through the Department of Industry and Trade also has several efforts that will be made to increase exports of Lampung cocoa commodities in the European Union Market. These efforts include: providing information to export business actors regarding export opportunities for cocoa commodities to non-traditional markets that are still untouched by exporters in Lampung as well as coordinating with relevant agencies, forming the Lampung Export Forum to jointly and synergize in order to increase exports of Lampung's superior products, one of which is cocoa.

Cocoa produced by Indonesian farmers is potential and has the opportunity to dominate the market, but the price of cocoa from Indonesian farmers is still very low. This is because Indonesian cocoa is still exported in the form of beans and has not been processed. The exported cocoa beans are not fermented, so there is still a lot of dirt attached to the cocoa beans [10]. Insects, fungi, and mycotoxins are also widely attached to cocoa beans. The inhibiting factor why cocoa beans are not fermented is that the difference between the price of fermented and unfermented cocoa beans is very small. Thus, most of the cocoa farmers in Lampung are reluctant to ferment their cocoa beans. This is because the fermentation of cocoa beans takes a long time. Even fermented cocoa beans, have to wait for the cocoa beans to be really old to be picked. Therefore, cocoa farmers feel that the price they get from fermenting cocoa beans is not commensurate with the effort they have put in. In addition, many cocoa farmers do not understand how to carry out the cocoa bean fermentation process. So that the development of cocoa farmers becomes very important, considering that processed cocoa products have a higher value when compared to unprocessed cocoa.

\section{Commercial Diplomacy Carried Out At The Global Level}

Indonesia has carried out economic diplomacy as well as commercial diplomacy to increase cocoa exports to the European Union market. Diplomatic efforts are mainly carried out to European Union countries with the aim of eliminating tariff discrimination on Indonesian cocoa products so that Indonesia can compete with other cocoa-producing countries such as Ghana and Ivory Coast in the European market. Some of these diplomatic efforts are:

- Commercial diplomacy at the central government level is carried out through Indonesia - the European Union Comprehensive Economic Partnership Agreement (IEU-CEPA). The Indonesian Ministry of Agriculture through the diplomatic forum IEU - CEPA has carried out diplomatic cooperation and trade efforts to reduce cocoa tariffs in Europe as well as increase Indonesian processed cocoa consumption in the region.

- Indonesia is a member of the International Cocoa Organization (ICCO). By becoming a member of the ICCO, the biggest benefit expected by Indonesia is the ease of access to lobbying European Union countries to reduce the import duty on processed cocoa to $0 \%$.

- Indonesian cocoa diplomacy in the world chocolate exhibition, Salon du Chocolat in Paris, France. Salon Du Chocolat is the world's largest chocolate exhibition held in several cities in the world, including Paris. Indonesia took advantage of the huge trade potential at 
this event to introduce domestic chocolates that were of equal and even better quality than the world-renowned chocolates.

In addition to the diplomatic efforts that have been carried out, Indonesia also needs to take advantage of opportunities in cooperation with these European countries. These countries have the opportunity to become targets for Indonesia to expand its business through cocoa or chocolate. An example is Switzerland. Switzerland is the country with the largest cocoa enthusiasts in the European Union. Cocoa processed in Switzerland is cocoa from Indonesia. Cocoa exported to Switzerland consists of several types, namely: Criollo cocoa (high grade) grown in a number of Central American countries; Trinitario (high grade) originating from Trinidad and grown in a number of Central American countries, Southeast Asia including Indonesia, with a production capacity of $10 \%-15 \%$ of the total world cocoa production; and Forastero (common grade) grows mostly on the African continent, which is $80 \%$ of the world's cocoa production [11].

The report published by the Embassy of the Republic of Indonesia Bern-Switzerland (July 2018), stated that the consumption of sustainable chocolate products (sustainable chocolate) in Switzerland continues to increase, for example, products that have organic or fairtrade certificates. The Swiss Platform for Sustainable Cocoa (SPSC) sets three criteria for sustainable chocolate products, namely that they are produced and have sustainable certification from internationally recognized institutions such as the Rainforest Alliance, Sustainable Agriculture Network, UTZ, or The European Committee for Standardization; or produced based on their own procedures that are relatively in accordance with the standards set by the sustainability certification body above; or follow other standards in accordance with the principles of the Sustainable Development Goal.

Some of the recommendations given by the Embassy of the Republic of Indonesia BernSwitzerland (July 2018) for Indonesian cocoa exporters so that they can increase Indonesian cocoa exports in the European Union market are as follows:

- In order to export cocoa beans that have a sustainable certificate, Indonesian cocoa entrepreneurs need to discuss with trading partners in Switzerland about the most suitable certification. The Indonesian government can be a facilitator for Indonesian cocoa entrepreneurs and trading partners in Switzerland. Sustainability certification can also be obtained in consultation with SwissContact in Indonesia and following the standards of the existing sustainable cocoa program in Indonesia.

- Cocoa beans exported to Switzerland are generally processed into chocolate in Switzerland. If Indonesian exporters have sufficient technical capacity and capital,
Indonesian exporters can ask Switzerland to cooperate in processing semi-finished chocolate according to Swiss standards. This could be directed at Swiss company investments, for example in the form of providing training for farmers to produce better quality cocoa beans. Good quality cocoa beans that have specific authenticity can attract Swiss SMEs, especially Swiss SMEs who want to buy directly from cocoa-producing countries. Indonesian exporters need to get Swiss SMEs to import cocoa that has been processed in Indonesia because the price will be higher.

- Indonesian cocoa exporters need to focus on exports of premium quality cocoa, for example, fine flavor or single origin cocoa. Competing with cocoa from African countries will be difficult for Indonesia because African countries produce in large quantities and at low prices. If Indonesian cocoa exporters will focus on the premium market (specialty or fine flavor cocoa), they are advised to use direct trade routes. Indonesian cocoa exporters should try to establish direct trade relations with small and medium business chocolate traders, specialty chocolate shops, chocolatiers, or bakeries in Switzerland. Indonesian exporters also need to keep abreast of price developments through the International Cocoa Organization's monthly market review. Indonesian exporters can follow the development trend of chocolate demand in the European market through the Confectionarynews website. Indonesian exporters need to keep abreast of regulatory developments in the European Union because Swiss regulations regarding imported cocoa will refer to the European Union's import food regulations. Indonesian cocoa exporters need to study in-depth the quality requirements to enter the European market on the Cocoa Quality website, learn how to maintain the cocoa quality during the shipping process on the Transportation Information Service website, and follow developments in international standards for cocoa quality [20]. Indonesian exporters need to keep abreast of regulatory developments in the European Union because Swiss regulations regarding imported cocoa will refer to the European Union's import food regulations. Indonesian cocoa exporters need to study in-depth the quality requirements to enter the European market on the Cocoa Quality website, learn how to maintain the cocoa quality during the shipping process on the Transportation Information Service website, and follow developments in international standards for cocoa quality [11]. Indonesian exporters need to keep abreast of regulatory developments in the European Union because Swiss regulations regarding imported cocoa will refer to the European Union's import food regulations. Indonesian cocoa exporters need to study in-depth the quality requirements to enter 
the European market on the Cocoa Quality website, learn how to maintain the cocoa quality during the shipping process on the Transportation Information Service website, and follow developments in international standards for cocoa quality [11].

- Indonesian exporters need to actively attend international exhibitions of chocolate food products in Switzerland or other European countries. This is done not only to find out the development of market trends, quality but also to get distribution channels or potential buyers, either directly or indirectly. Some of the most famous chocolate trade shows in Europe are the Salon du Chocolat in Paris and the Festicoc in Geneva. Communication with potential buyers can enrich the knowledge of Indonesian exporters about the authenticity of cocoa beans, flavors, and sustainable cocoa. Indonesian exporters can use the Swiss Chocolate Association, Chocosuisse, to find potential buyers in Switzerland by visiting its website.

- Exporters also need to identify the main competitors of cocoa exporters from other countries and study their various strategies, for example marketing methods (through websites, social media), product characteristics (authenticity, quality, oil content), other added values (certification and product process techniques). Some sites from several cocoaproducing countries that can be studied include girlfriends (Ecuador), Ingemann (Nicaragua), and XocoGuormet (Nicaragua).

The Indonesian government also needs to immediately negotiate the import duty on Indonesian cocoa to $0 \%$ through a trade agreement with Europe. Currently, Indonesian cocoa products are still subject to an entry fee of $4-5 \%$. This is different from other cocoa-producing countries where the tariffs are small, not even an entry fee $(0 \%)$, such as Ivory Coast and Ghana. These two countries occupy the top rank in world cocoa exports. Indonesia does not receive a $0 \%$ tariff for processed cocoa products because some of Indonesia's cocoa products do not meet the criteria and requirements set by Europe. Meanwhile, cocoa from Ivory Coast and Ghana has been equipped with European-recognized certifications [12].

Based on a report made by the Embassy of the Republic of Indonesia Bern-Switzerland (July 2018), there are several certifications that need to be considered by Indonesian exporters in exporting cocoa beans and cocoa products to Europe, especially Switzerland, such as [11]

- Sustainability Certification: sustainability includes social, environmental, and economic aspects. European countries including Switzerland set a number of conditions for sustainable certification, namely the use of underage labor, healthy working conditions, deforestation, use of pesticides. There are several sustainability certification schemes that have different emphases. UTZ and Rainforest are the most widely used sustainable cocoa certification bodies in the world. In 2017 the two institutions merged with the Rainforest Alliance.

- Food Security Certification: Food safety is of paramount importance in the European food market. Almost all food importers in Switzerland will require the implementation of a Quality Management System in their production and handling processes. All European buyers will request the application of a Hazard Analysis Critical Control Point (HACCP)

- Organic Certification: buyers in Switzerland and Europe are generally very concerned about food with high health standards including food that has organic certification. Indonesian exporters need to study organic food certification on the European Commission's trade helpdesk website.

- Fair Trade Certification: this certification is required to prove the transparency of business performance during the production and distribution process. The institution that provides Fair Trade certification is the International Trade Center (ITC).

\section{Effectiveness of Commercial Diplomacy Carried Out at The Local and Global Levels}

The effectiveness of commercial diplomacy can be seen from its long-term (indirect effect) and short-term (direct effect) goals. The long-term goal (indirect effect) is achieved or not seen from the amount of Lampung's domestic cocoa production, the number of farmers and annual revenues, and the increase in the Gross Regional Domestic Product of Lampung Province. Commercial diplomacy efforts that have been carried out by the Industry and Trade Office of Lampung Province were followed by an increase in cocoa production in Lampung Province from 2014 to 2018. In 2014, Lampung produced 28,067 tons of cocoa and became 58,251 tons in 2018 [13]

This increase could be due to a direct approach from the Industry and Trade Office of Lampung Province to farmers regarding cocoa export opportunities. Through this approach, farmers began to realize that cocoa production has a fairly high business value. Gradually, the cocoa farmers also began to understand the ways of cocoa production through the guidance provided by the Agricultural Quarantine Center. Then, the Industry and Trade Office of Lampung Province has also held a cocoa exhibition and collaborated directly with the Ministry of Trade of the Republic of Indonesia. Furthermore, the number of cocoa farmers in Lampung Province reached 116,259 people or about $10.25 \%$ of the total plantation farmers. The large number of farmers is able to generate revenue of. $22,122,140.57$ rupiah per 
year from cocoa production [14]. Thus, the cocoa production business in Lampung Province can increase employment opportunities and increase the income of the local community.

Then, the long-term goals and indirect impacts of commercial diplomacy that have been carried out by the Industry and Trade Office of Lampung Province can also be seen from the increase in the Gross Regional Domestic Product of Lampung Province in the plantation sector which contains cocoa commodities. The Gross Regional Domestic Product of Lampung Province in the plantation sector continued to increase from 2015 to 2020. In 2015, the Gross Regional Domestic Product of Lampung Province in the plantation sector was valued at $17,709,543.99$ rupiah and became 21,772,708.87 rupiah in 2020 [15]. Therefore, the indirect impact in the long term, diplomatic efforts The commercial activities carried out by the Industry and Trade Office of Lampung Province have been quite good.

The effectiveness of commercial diplomacy for short-term (direct effect) can be seen from the commercial diplomacy efforts that have been carried out by the central government at the global level. The short-term goals and the direct impact of achieving or not can be seen from the increasing number of Indonesian cocoa exports to European Union countries.

TABLE I. EXPORT OF COCOA BEANS, WHOLE OR DAMAGED, RAW OR ROASTED FROM INDONESIA TO EUROPEAN UNION COUNTRIES

\begin{tabular}{|l|l|l|l|l|l|l|}
\hline \multirow{2}{*}{ Importers } & \multicolumn{6}{|c|}{ Exported Quantity per Years, Tons } \\
\cline { 2 - 8 } & $\mathbf{2 0 1 5}$ & $\mathbf{2 0 1 6}$ & $\mathbf{2 0 1 7}$ & $\mathbf{2 0 1 8}$ & $\mathbf{2 0 1 9}$ & $\mathbf{2 0 2 0}$ \\
\hline Belgium & 200 & - & 241 & 182 & 568 & 625 \\
\hline Netherlands & 547 & 118 & 1 & 75 & 151 & 18 \\
\hline France & 13 & 14 & 13 & 5 & 0 & 13 \\
\hline Germany & 565 & 25 & 38 & 37 & 100 & 3 \\
\hline Estonia & 5 & - & - & 92 & - & - \\
\hline Italy & 50 & - & - & - & - & - \\
\hline
\end{tabular}

a. Source: ITC calculations based on UN COMTRADE and ITC statistics, processed

Based on the table above, the number of Indonesian cocoa exports to European Union countries has increased, decreased, and stopped. Belgium is a dispersed importer of cocoa than other European Union countries. From 2015 to 2020 there was an increase, except for 2017 [16]. Then, the Netherland, France, Germany, and Estonia countries which initially imported large quantities of cocoa in 2015 decreased in quantity in the following years. Then, Indonesia's cocoa exports to Italy stopped from 2016 to 2020. Even though there have been efforts made by the central government to increase cocoa exports to European Union countries. Efforts through Indonesia - the European Union Comprehensive Economic Partnership Agreement (IEU-CEPA), Some of the recommendations given by the Embassy of the Republic of Indonesia Bern-Switzerland, and other efforts. Therefore, commercial diplomacy efforts carried out by the Indonesian central government to increase cocoa exports still need to be improved. So that the direct impact of commercial diplomacy can be realized.

\section{CONCLUSION}

Cocoa is one of Lampung's leading commodities. Lampung Province is currently actively carrying out commercial diplomacy activities, especially to increase exports of superior commodities to various countries. Lampung's cocoa exports are expected to increase in the international market, one of which is to countries in the European Union. Countries such as Switzerland, Germany, England, and Ireland are potential markets for Lampung to expand its business through cocoa or chocolate.

Commercial diplomacy at the local level that has been carried out by the Lampung Provincial Government, through the Department of Industry and Trade, consists of conducting trade promotions by sending cocoa samples to several countries such as Japan, India, Malaysia, Germany, Chile, and Dubai as well as involving business actors to take part in exhibitions by displaying various Lampung's superior commodities (one of which is cocoa) and providing information to buyers or investors that the productivity of the commodity cocoa in Lampung has competitiveness with cocoa commodities in various cocoa-producing countries.

To increase exports of Lampung cocoa commodities to the European Union market, the Lampung Provincial Government held activities such as FGDs on the Acceleration of Trade Negotiations, Export Coaching for export-oriented SMEs, and in collaboration with the Ministry of Trade of the Republic of Indonesia. The cooperation carried out by the Government of Lampung Province with the Ministry of Trade is in the form of: training to get buyers through Digital Marketing and other facilitation of coaching such as socialization of providing information on global market opportunities, export training for prospective exporters and exporters of cocoa. In addition, the Lampung Provincial Government also cooperates with farmer groups.

The Government of Lampung Province through the Department of Industry and Trade also has several efforts to increase exports of Lampung cocoa commodities in the European Union Market. These efforts include: providing information to export business actors regarding export opportunities for cocoa commodities to non-traditional markets that are still untouched by exporters in Lampung as well as coordinating with relevant agencies, forming the Lampung Export Forum to jointly and synergize in order to increase exports of Lampung's superior products, one of which is cocoa.

Meanwhile, diplomacy at the global level that has been carried out by the Government of Indonesia consists of: commercial diplomacy at the central government level carried out through IIEU-CEPA to reduce cocoa tariffs in Europe while increasing 
consumption of Indonesian processed cocoa in the region; Indonesia is a member of ICCO. The biggest benefit expected by Indonesia is the ease of access to lobby European Union countries to reduce the import duty on processed cocoa to $0 \%$; and Indonesian cocoa diplomacy in the world chocolate exhibition, Salon du Chocolat in Paris, France. The huge trading potential at this event was used by Indonesia to introduce domestic chocolates that have the same quality and even better quality than the world-renowned chocolates.

In addition to the diplomatic efforts that have been carried out, Indonesia also needs to take advantage of opportunities in cooperation with these European countries. These countries have the opportunity to become targets for Indonesia to expand its business through cocoa or chocolate. An example is Switzerland. Switzerland is the country with the largest cocoa enthusiasts in the European Union. The Indonesian government needs to provide support and assistance to Indonesian cocoa exporters or entrepreneurs so that they can meet the criteria for sustainable chocolate products set by Switzerland. The Indonesian government can be a facilitator for Indonesian cocoa entrepreneurs and trading partners in Switzerland. In addition, the Indonesian government can work with Switzerland to provide training so that farmers can produce better quality cocoa beans and so that Indonesian exporters have the technical capacity and sufficient capital to process semi-finished chocolate according to Swiss standards. The Indonesian government also needs to provide support so that Indonesian exporters can attend international exhibitions of chocolate food products in Switzerland or other European countries.

The Indonesian government also needs to immediately negotiate the import duty on Indonesian cocoa to $0 \%$ through a trade agreement with Europe. Currently, Indonesian cocoa products are still subject to an entry fee of $4-5 \%$. This is different from other cocoa-producing countries where the tariffs are small, not even an entry fee $(0 \%)$, such as Ivory Coast and Ghana. Indonesia does not receive a $0 \%$ tariff for processed cocoa products because some of Indonesia's cocoa products do not meet the criteria and requirements set by Europe. Several certifications need to be considered by Indonesian exporters in exporting cocoa beans and cocoa products to Europe, especially Switzerland, such as Sustainability Certification, Food Security Certification, and Organic Certification. Then, diplomacy carried out at the local level has been quite effective. Meanwhile, commercial diplomacy at the global level still needs to be improved. It aims to achieve the effectiveness of commercial diplomacy on cocoa that has been carried out.

\section{REFERENCES}

[1] Kontan.co.id. "Kebutuhan Kakao Uni Eropa Terus Bertambah: Peluang Emas Untuk Indonesia”. Accessed: 4 Desember https://exportexpert.kontan.co.id/news/kebutuhan-kakao-unieropa-terus-bertambah-peluang-emas-untuk-indonesia.

[2] Woolcock, S. 2007a. Theoretical Analysis of Economic Diplomacy dalam Bayne, N \& Woolcock, S (eds). 2007. The New Economic Diplomacy: Decision-Making and Negotiations in International Economic Relations. Ashgate Publishing Company.

[3] Rana, K. S. 2007. Economic Diplomacy: Experience of Developing Countries dalam Bayne, N \& Woolcock, S (eds). 2007. The New Economic Diplomacy: Decision-Making and Negotiations in International Economic Relations. Ashgate Publishing Company.

[4] Killian, P.M.E. 2013. Pemerintah Daerah dalam Diplomasi Ekonomi Indonesia : Studi Kasus pada Diplomasi Komersial Jawa Timur. Jurnal Ilmiah Transformasi Global. Vol 2 No 2.

[5] Huub Ruel and Lennart Zuidema, 2012, The Effectiveness of Commercial Diplomacy, Belgium: Netherlands Institute of International Relations 'Clingendael'.

[6] Jens Holscher \& Horst Tomann, 2015, "Palgrave Dictionary of Emerging Markets and Transition Economics", Palgrave Macmillan.

[7] Directorate General of Estate Indonesia, Cocoa Production by Province in Indonesia 2017 - 2021. Available: https://www.pertanian.go.id/home/index.php?show=repo\&file Num=209

[8] Directorate General of Estate Indonesia, Cocoa Area by Province in Indonesia 2017 - 2021. Available: https://www.pertanian.go.id/home/index.php?show=repo\&file Num=224

[9] International Trade Map, List of exporting companies in Indonesia for the following product Product category : Chocolate and cocoa products. Available: https://www.trademap.org/CompaniesList.aspx?nvpm $=1 \% 7 \mathrm{c} 3$ $60 \% 7 \mathrm{c} \% 7 \mathrm{c} \% 7 \mathrm{c} \% 7 \mathrm{c} 18 \% 7 \mathrm{c} \% 7 \mathrm{c} \% 7 \mathrm{c} 2 \% 7 \mathrm{c} 1 \% 7 \mathrm{c} 1 \% 7 \mathrm{c} 2 \% 7 \mathrm{c} 3 \%$ $7 \mathrm{c} 1 \% 7 \mathrm{c} 2 \% 7 \mathrm{c} 1 \% 7 \mathrm{c} 1 \% 7 \mathrm{c} 4$

[10] Interview with the Industry and Trade Office of Lampung Province, May 2021

[11] Kedutaan Besar Republik Indonesia Bern, Switzerland. 2018. Informasi Pasar Swiss: PeluangEksporKakaoke Swiss. EdisiJuli2018.

https://pasaramerop.kemlu.go.id/images/pdffiles/publikasi/Inf ormasi_Pasar_Swiss_Peluang_Ekspor_Kakao_ke_Swiss.pdf.

[12] Satrio, R. 2021. Kebijakan Kakao Indonesia dan Ghana Terhadap Pasar Eropa Tahun 2013-2018. Fakultas Ilmu Sosial dan Ilmu Politik, Universitas Pembangunan Nasional "Veteran" Jakarta.

[13] Badan Pusat Statistik Provinsi Lampung, Produksi Tanaman. Available:

https://lampung.bps.go.id/indicator/54/258/1/produksitanaman.html

[14] Stella Ayu Anggraeni, Fembriarti Erry Prasmatiwi, and Suriaty Situmorang, 2018, Analisis Pendapatan dan Pemasaran Kako di Kecamatan Bulok Kabupaten Tanggamus, Jurusan Agribisnis, Fakultas Pertanian, Universitas Lampung, JIIA, VOLUME 6 No. 3, AGUSTUS 2018.

[15] Badan Pusat Statistik Provinsi Lampung, Produk Domestik Regional Bruto Menurut Lapangan Usaha (Juta Rupiah), 2019-2020. Available: https://lampung.bps.go.id/indicator/52/39/1/produk-domestikregional-bruto-menurut-field-usaha.html

[16] International Trade Map (ITC), List of importing markets for a product exported by Indonesia. Product: 1801 Cocoa beans, whole or broken, raw or roasted, Available: https://www.trademap.org/Country_SelProductCountry_TS.a spx?nvpm $=1 \% 7 \mathrm{c} 360 \% 7 \mathrm{c} \% 7 \mathrm{c} \% 7 \mathrm{c} \% 7 \mathrm{c} 1801 \% 7 \mathrm{c} \% 7 \mathrm{c} \% 7 \mathrm{c} 4 \% 7$ $\mathrm{c} 1 \% 7 \mathrm{c} 1 \% 7 \mathrm{c} 2 \% 7 \mathrm{c} 2 \% 7 \mathrm{c} 1 \% 7 \mathrm{c} 2 \% 7 \mathrm{c} 1 \% 7 \mathrm{c} \% 7 \mathrm{c} 1$ 